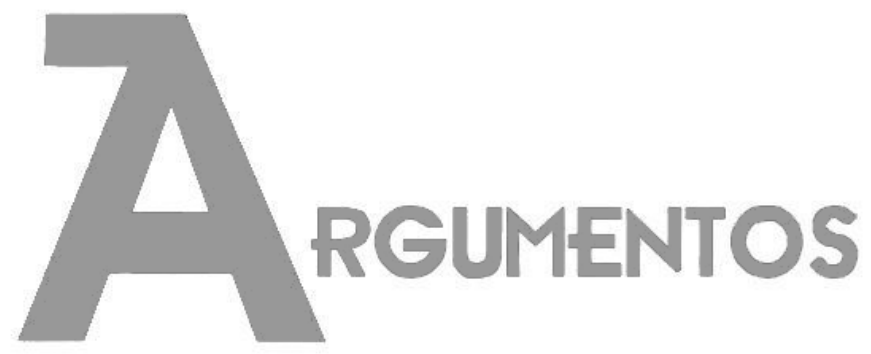

Vol. 16, n. 1, jan./jun. 2019 ISSN: 2527-2551 (online)

\title{
Povo de terreiro, povo de axé ou comunidades tradicionais de matriz africana: identidade afro-religiosa na esfera pública
}

\author{
Taísa Domiciano Castanha ${ }^{1}$
}

Recebido em: 12/11/2018

Aprovado em: 14/03/2019

Resumo: $O$ presente artigo tem como objetivo analisar a emergência da identidade do grupo religioso afro-brasileiro na esfera pública. Baseado em uma análise da Audiência Pública ocorrida na Assembleia Legislativa de Minas Gerais em setembro de 2017, busca-se discutir os processos de construção de uma identidade afro-religiosa nos quais tradição, ancestralidade e intolerância religiosa ocupam um lugar de destaque. Nesse sentido, povo de terreiro, comunidades tradicionais de matriz africana e povo de axé são interpretados como categorias identitárias que abarcam tanto a heterogeneidade do campo religioso afro-brasileiro como a diversidade de perfil de seus praticantes.

Palavras-chave: identidade; religiões afro-brasileiras; esfera pública; intolerância religiosa; tradição.

\section{Pueblos originarios, pueblos de axé en comunidades tradicionales de origen africano: identidad afro-religiosa en la esfera pública}

Resumen: El presente articulo tiene como objetivo analizar la emergencia de identidad de los grupos religiosos afro-brasilerosen la esfera publica. Basado en un análisis de Audiencia Publica ocurrido en la Asamblea Legislativa de Minas Gerais en Septiembre del 2017, se busca discutir el proceso de construcción de una identidad afro-religiosa en los que la tradicion, ancestralidad e intolerancia religiosa ocupan un lugar destacado. En esse sentido, los pueblos originarios, comunidades tradicionales de origen africanas y pueblos de axé son interpretados como categorias de identidad que abarcan tanto la heterogeneidad de los campos religiosos afrobrasileiros como la diversidad de los perfiles de sus praticantes.

Palabras-clave: identidad; religiones afrobrasileñas; esfera pública; intolerância religiosa; tradición.

\footnotetext{
1 Doutoranda em Estudos Étnicos e Africanos pela Universidade Federal da Bahia - Salvador, Brasil. Email:<taisadomiciano@gmail.com >. ORCID: https://orcid.org/0000-0003-3840-2868.
} 


\title{
People of terreiro, people of axé or traditional african matrix communities: afro- religious identity in the public sphere
}

\begin{abstract}
This article aims to analyze the emergence of Afro-Brazilian religious group identity in the public sphere. Based on an analysis of the Public Hearing held at the Legislati ve Assembly of Minas Gerais in September 2017, the aim is to discuss the processes of building an Afro-religious identity in which tradition, ancestry and religious intolerance occupy a prominent place. In this sense, terreiro people, traditional communities of African matrix and people of axé are interpreted as identity categories that embrace both the heterogeneity of the Afro-Brazilian religious field and the diversity of profile of its practitioners.
\end{abstract}

Keywords: identity; Afro-Brazilian religions; public sphere; religious intolerance; tradition.

\section{Introdução}

A emergência de "novas" identidades na esfera pública brasileira tem se tornado uma constante nos últimos anos e chamado a atenção de variados pesquisadores (COSTA, 2013; MORAIS, 2017). Mudanças recentes no país, sobretudo a partir da década de 2000, colocaram em evidência as chamadas religiões afro-brasileiras, sobretudo pelo aparecimento do movimento afro-religioso na esfera pública, através da associação com movimento negro, que culminou na inclusão das religiões afro-brasileiras em variadas políticas públicas (MORAIS, 2015; 2017).

Tendo em vista esse panorama no qual raça, etnicidade, religião, tradição e ancestralidade se entrecruzam no discurso identitário, este artigo busca refletir sobre a seguinte questão: como são sustentadas as identidades dos religiosos afro-brasileiros na esfera pública? Para dar conta desse objetivo, busco analisaro processo de formação dos arranjos identitários coletivos, que culminou em identidades como povo de terreiro, povo de axé e comunidades tradicionais de matriz africana.

Dessa forma, este artigo busca analisar o processo de construção de identidade dos grupos religiosos afro-brasileiros na esfera pública do Estado, a partir da década de 2000, chamada aqui de identidade afro-religiosa e serão analisados três principais elementos acionados por essa identidade: tradição, ancestralidade e intolerância religiosa. Em síntese, busco desvelar as formas de agenciamento e construção da identidade afro-religiosa, seguindo a indicação de Sansone (2004) para usar uma "abordagem pragmática" na análise das identidades étnicas, a qual exponha os variados 
arranjos possíveis do aparecimento dessas identidades na atualidade ${ }^{2}$. Para isso, utilizo como fonte os discursos proferidos na Audiência Pública ocorrida em 26 de setembro de 2017 na Assembleia Legislativa de Minas Gerais, cuja pauta foi a liberdade de culto às religiões afro-brasileiras ${ }^{3}$. A minha participação nesta assembleia foi fruto de trabalho de campo feito na cidade de Belo Horizonte e região metropolitana para minha dissertação de mestrado ${ }^{4}$.

\section{Identidade na sociedade contemporânea: entre a essência e o relacional}

O conceito de identidades étnicas ou etnicidade entrou em cena nas Ciências Sociais na década de 1950, após a Segunda Guerra Mundial, como um "substituto" à ideia de "raça"5. Tendo em vista o Holocausto Judeu e a operacionalização do conceito de raça pelo nazismo para extermínio do outro, a então incipiente Organização das Nações Unidas para a Educação, a Ciência e a Cultura (Unesco) produziu dois importantes documentos ${ }^{6}$ refutando o lugar do conceito de raça como categoria

\footnotetext{
2 "Sustento que melhor seria usarmos uma abordagem mais pragmática da identidade negra - expondo todas as suas formas possíveis de a parecimento, em vez de nos concentrarmos apenas nas poucas formas que se enquadram em nossa abordagem teórica" (SANSONE, 2004: 25).

${ }^{3} \mathrm{~A}$ audiência pública na Assembleia Legislativa de Minas Gerais fez parte da 16으 reunião ordinária da Comissão de Participação Popular com a finalidade de debater "o direito à liberdade de cul to e o respeito às tradições das religiões afro-brasileiras" (Fonte:https://www.almg.gov.br/atividade parlamentar/comissoes/internaPauta.html ?idCom=585\&dia $=26 \&$ mes $=09$ \&ano=2017\&hr=14:30\&tpCom=1\&aba=js tabResultado Acesso 16 de maio de 2018).

${ }^{4}$ CASTANHA, Taísa Domiciano. "Religiões afro-brasileiras em Belo Horizonte e região metropolitana: conflitos, violências e legitimação" PPGS/UFMG, 2018.

${ }^{5} \mathrm{O}$ termo raça está grafado entre aspas pois tal como será apresentado e discutido, a noção biológica de raça - enquanto um grupo social geneticamente homogêneo - não existe; porém, raça exis te enquanto uma construção social. Dessa forma, segui a mesma diretriz usada por Eriksen (2010): "O termo "raça" deliberadamente foi colocado dentro de aspas, a fim de enfatizar que não é um termo científico. Considerando que foi durante algum tempo na moda dividir a humanidade em quatro raças principais, e os rótulos raciais ainda são usa dos para classificar as pessoas emalguns países (como os EUA), a genética moderna tende a não falar de raças. Existem duas razões principais para isso. Primeiro, sempre houve tanto cruzamento entre as populações humanas que seria inútil falar de fronteiras fixas entre as raças. Em segundo lugar, a distribuição de características físicas hereditárias não segue limites claros (Cavalli Sforza et al., 1994). Em outras palavras, há em muitos aspectos maior variação genética dentro de um grupo "racial" do que há variação sistemática entre dois grupos. Terceiro, nenhum estudioso sério acredita que as características hereditárias explicam as variações culturais. (...) Conceitos de raça podem, no entanto, ser relevantes na medida em que informam as ações das pessoas; nesse nível, a raça existe como uma construção cultural, tenha ou não uma realidade biológica (ver também Banks, 1996: 54; Jenkins, 2008: 23-4). O racismo, obviamente, baseia-se na suposição de que a personalidade está de alguma forma ligada a características hereditárias que diferem sistematicamente entre "raças", e dessa forma a raça pode assumir importância sociológica mesmo que não tenha existência "objetiva""'. ${ }^{6}$ Declaração sobre a raça (1950) e Declaração sobre a raça e as diferenças raciais (1951).
} 
explicativa, advogando em prol do conceito de etnia. Nesse sentido, a substituição do uso do termo raça por etnia na década de 1950 apontava para a dimensão sociológica e psicológica da produção das diferenças, contrariando a noção puramente biológica de raça (SANSONE, 2014; FURTADO, 2014).

Fredrik Barth, com a publicação de Grupos étnicos e suas fronteiras, em 1969, lançou as bases teóricas para consolidar o termo etnicidade nas Ciências Sociais. O impacto causado nesta área de estudos pela publicação do texto de Fredrik Barth foi significativo e ratificou alguns pressupostos sobre etnicidade - os quais continuam válidos ate hoje - tornando este termo hegemônico nos estudos sobre organização social e sobre cultura. Tal como escrevem Vermeuelen e Govers (2003: 10):

"poucas dúvidas existem sobre o papel essencial que a introdução de Barth em Ethnic Groups and Boundaries tem vindo a desempenhar. Mais do que qualquer outro texto, este último tornou-se um marco simbólico das mudanças para as quais contribuiu substancialmente, sendo considerado, desde cedo, um clássico."

Basicamente, a Barth é creditado o mérito de tratar os grupos étnicos por uma perspectiva interacionista e relacional, cujo foco está nas bordas e fronteiras, em detrimento de abordagens estáticas da identidade, as quais privilegiam o conteúdo desses grupos étnicos. Assim, o foco deixa de ser o material cultural que se expressa pela identidade étnica, passando a figurar nas análises o modo como as fronteiras entre grupos são produzidas em cada contexto, tendo em vista a oposição entre um "nós" e um "eles". Por isso, é primordial para a definição do pertencimento étnico a ascrição e auto-ascrição de seus membros. O papel da cultura em relação à identidade étnica é, sobretudo, atuar como marcador das distinções, das fronteiras; ou seja, é a partir da cultura e principalmente das diferenças culturais que os sinais diacríticos são escolhidos.

Em suma, a perspectiva relacional da identidade étnica pode ser sintetizada nos seguintes pontos (BARTH, 1969, 2003; ERIKSEN, 2000): primeiro, para a formação de identidade étnica deve haver um outro grupo de contraste, por isso a abordagem está na relação entre grupos e não apenas em um grupo específico. Portanto, o termo "identidade étnica" se refere a um aspecto de uma "relação interétnica" e não uma propriedade de um grupo. Segundo, as fontes de solidariedade e identificação coletiva do grupo étnico devem ter por base o compartilhamento de características culturais 
específicas: os traços diacríticos culturais. O terceiro ponto em comum às identidades étnicas é que elas podem assumir as mesmas origens; ou seja, os grupos étnicos compartilham "mitos de origem comum".

Essas abordagens da identidade como relacional - em detrimento de abordagens identitárias essencializadas, cujas premissas são o indivíduo fixo, biológico, integrado e possuidor de um núcleo interior racional - foram extremamente úteis aos estudos das religiões afro-brasileiras, uma vez que o contínuo entre "raça" e cultura perdurou nas pesquisas acadêmicas até a década de 1960, reproduzindo, implícita ou explicitamente, a correlação entre religiões afro-brasileiras e os negros, deixando de lado as complexas construções identitárias no contexto social brasileiro.

O estudo das chamadas religiões afro-brasileiras se deparou com a questão entre "raça" e cultura desde a sua gênese (CRUZ, 2008). Nina Rodrigues, o famoso professor da Escola de Medicina da Bahia e considerado pioneiro nas pesquisas acadêmicas sobre Candomblé7, foi categórico em reputar as diferenças culturais - inclusive a religião como produto biológico das diferentes "raças" existentes no Brasil. Assim, com uma perspectiva essencialista tanto de "raça" como de cultura (entendida como civilização), o Candomblé e demais traços culturais dos negros seriam passados geneticamente de geração a geração. A visão de Nina Rodrigues sobre o sincretismo religioso ilustra bem como essas duas variáveis - "raça" e cultura - são elementos considerados correspondentes: altamente influenciado pelo evolucionismo e por uma perspectiva racista vigente em fins do século XIX, Nina Rodrigues acreditava que os negros compunham uma "raça" inferior e por isso não conseguiam se converter de fato ao catolicismo e absorver suas abstrações monoteístas, usando constantemente a associação com seus deuses de origem. Nesse sentido, o aparato biológico neurocognitivo dos negros seria inferior - tendo como consequência manifestações culturais inferiores - se comparado com a "raça branca", biologicamente superior (RODRIGUES, 2010).

Seguindo o contínuo entre "raça" e cultura, de maneira mais sofisticada e complexa, Roger Bastide também interpreta o Candomblé como uma "civilização e

\footnotetext{
${ }^{7}$ O animismo fetichista dos negros baianos, publicado entre 1896 e 1897, é considerado o marco inicial nos estudos das religiões afro-brasileiras.
} 
metafísica africana" (BASTIDE, 2001) ${ }^{8}$. Herdeiro de um pensamento que preconizava o fim e degeneração dos elementos culturais africanos pela "mestiçagem", esse sociólogo francês via o Candomblé - sobretudo o ketu de modelo baiano - como preciosos redutos do legado das civilizações africanas no Brasil. Para Bastide, os negros nagôs vindos da África conseguiram formar cultos organizados, religiosos, com preservação das "tradições", sendo o expoente maior o Candomblé ketu na Bahia. Por outro lado, os cultos praticados por outros povos africanos, como os bantus, que povoaram o sudeste do Brasil, se degeneraram devido à "mestiçagem", não se organizaram e se transformaram em magia (BASTIDE, 1971) ${ }^{9}$. Portanto, o Candomblé - sobretudo o ketu - é interpretado como ilhas de civilização africana, sendo que ingressar no Candomblé significa ingressar na "civilização africana" (BASTIDE, 1971; CRUZ, 2008).

A partir da década de 1960, as religiões afro-brasileiras ganharam visibilidade e adesão de pessoas brancas e de classe média, de modo que os processos identitários nessas religiões tornaram-se mais complexos (PRANDI, 1991). A associação - antes automática - entre religiões afro-brasileiras como conjunto de práticas e crenças de um grupo "racial" específico, dos negros, ficou cada vez mais difícil de sustentar. Com a ascensão da Umbanda no campo religioso brasileiro e com a expansão do Candomblé ketu ao sudeste, juntamente a um movimento contra cultural a nível global que questionou os valores Ocidentais, além da inserção de elementos afro-brasileiros na construção da identidade nacional, as religiões afro-brasileiras passaram por mudanças significativas. Nesse processo, as religiões afro-brasileiras deixaram de ser religiões étnicas, para se tornarem universais, abertas a todas as classes sociais, gênero e raça (PRANDI, 1991, 2000). No entanto, apesar dessas mudanças, o contínuo entre raça e cultura - presente na ideia dos terreiros como "ilhas africanas", guardiões de tradição e sustentáculo de ancestralidade negra - continua sendo acionado nas construções

\footnotetext{
8 "Examinando o mundo dos candomblés unicamente por intermédio dos candomblés, corre-se, com efeito, o risco de deixar escapar o que é para nós essencial: a estrutura da civilização africana." (Bastide 2001: 70).

9Essa dicotomia feita entre o Candomblé "puro" (e consequentemente verdadeiro, legítimo e superior) e o Candomblé "degenerado", mestiço e mais próximo à magia foi um ponto muito criticado por autores que se dedicam ao tema das religiões afro-brasileiras após Bastide (DANTAS, 1982; MAGGIE, 1975; CAPONE, 2004). Basicamente, as críticas direcionadas a Bastide argumentam que ao se estabelecer essa hierarquia com base em categorias nativas e não analíticas, qualificam-se os candomblés nagôs como melhores e, consequentemente, como objetos de estudo; já às "macumbas" degeneradas foram devotados poucos estudos ou quase nenhum, uma vez que as referências são escassas.
} 
identitárias dos religiosos afro-brasileiros, pelo movimento negro e também nas políticas públicas brasileiras, que desde o início dos anos 2000 passaram a incluir as religiões afro-brasileiras em várias áreas das políticas públicas, sobretudo nas políticas de promoção da igualdade racial (MORAIS, 2017).

Analisar a identidade religiosa dos praticantes afro-brasileiros sob a perspectiva relacional permite compreender os variados e complexos arranjos identitários que se desenvolveram ao longo do tempo, e que se expressam, por exemplo, na Audiência Pública da Assembleia Legislativa de Minas Gerais, quando pai Luiz de Odé, um jovem sacerdote fenotipicamente "mestiço", cujo terreiro foi alvo de intolerância religiosa e de grande repercussão local, se apresentou como "representante de sua religião", acionando marcadores de diferença como tradição, ancestralidade e intolerância religiosa:

"Eu tô expondo um problema [de intolerância religiosa] que não é só eu que estou passando, não é só a minha casa mas a religião em todo Brasil. (...) Há uns bons anos atrás, meus avós, meus antepassados lutaram para eu estar aqui hoje. E hoje está acabando... será que meus filhos, meus netos, os netos dos meus filhos, será que eles vão ter ainda aonde ir, a um terreiro para poder louvaro seu sagrado, lembrardo seu antepassado? Deixo essa pergunta pra ver se alguém vai me responder hoje. Será que a luta deles, o choro, a lágrima, o sofrimento que eles tiveram lá, pra hoje a gente tá aqui, foi em vão? Eu como representante da minha religião, adepto dela e quero continuar sendo, eu não vou deixar essa peteca cair. A minha casa não vai calar os tambores. Não tem concordância. A tolerância tem que partira partir deles. (...) Não é Ministério Público, não é o vizinho intolerante que vai me dizer como rezar. Eu tenho tradição e é isso que eu sigo" (Pai Luiz de Odé, Audiência Pública, 26 de setembro de 2017. Transcrição feita pela autora. Disponivel em https://www.youtube.com/watch?v=mFeOSuPUocg\&t=2315s).

\section{Audiência pública na ALMG: tradição e ancestralidade}

O discurso de Pai Luiz na Audiência Pública na Assembleia Legislativa de Minas Gerais (ALMG) elucida questões relacionadas às religiões afro-brasileiras, identidade e raça. Para entender melhor esse contexto, vou apresentar brevemente o caso de intolerância religiosa ocorrido no terreiro de pai Luiz de Odé, o llê Axé Sangô em Santa Luzia, região metropolitana de Belo Horizonte, que contou com grande repercussão local e indiretamente culminou na Audiência Pública na ALMG. 
O conflito em questão teve início na via jurídica em janeiro de 2015 , quando um casal de vizinhos do Ilê Axé Sangô acionou o Ministério Público de Minas Gerais (MPMG) e denunciou o terreiro por perturbação do sossego e poluição sonora devido ao barulho decorrente das suas atividades religiosas. No dia 30 de janeiro de 2015, o casal de vizinhos apresentou um abaixo-assinado ao MPMG, com pedido de "suspensão e dissolução do Centro Espírita" (Inquérito Civil Público no MPMG-0245.15.000031-4). A partir de então uma longa jornada de contenda envolvendo o llê Axé Sangô, o MPMG e o casal de vizinhos começou. No dia 08 de julho de 2015, foi celebrado um Termo de Ajustamento de Conduta (TAC) entre representantes do terreiro e o MPMG. De acordo com o Termo de Ajustamento de Conduta (TAC), que é um mecanismo extrajudicial previsto no ordenamento jurídico brasileiro e um instrumento muito usado no campo ambiental para resolução de conflitos, o proprietário do imóvel do terreiro Ilê Axé Sangô se comprometeu em apresentar em 90 dias uma vistoria do corpo de bombeiros no local, bem como um alvará de funcionamento na prefeitura de Santa Luzia, com a consequência de, caso não apresentasse, as atividades do terreiro seriam interrompidas; manter a emissão de som em nível máximo de 55 decibéis no período diurno e 50 decibéis no período noturno; além disso, o não cumprimento de qualquer obrigação assumida implicaria multa diária de $\mathrm{R} \$ 100,00$ (cem reais).

Devido à insatisfação de ambas as partes, à repercussão do caso e ao não cumprimento de alguns termos do TAC, no dia 21 de março de 2017 no MPMG se estabeleceu um novo TAC. Ficaram acordados entre as partes os seguintes pontos: as atividades do terreiro se limitariam às quartas-feiras no horário das 19:00 às 22:00 e um único sábado por mês, entre 15:00 e 20:00; a utilização de um único atabaque para as atividades religiosas; elaboração do projeto de isolamento acústico em 60 dias e execução do projeto de isolamento acústico em 270 dias. Essa foi a última movimentação no processo do Inquérito Civil Público até o presente momento.

Essas restrições impostas pelo MPMG ao llê Axé Sangô repercutiram na mídia mineira, acionaram redes de movimentos sociais, políticos, juristas, sacerdotes e adeptos das religiões afro-brasileiras. Durante o ano de 2017, acompanhei os desdobramentos desse caso na esfera pública e uma parte do trabalho de campo foi seguir as teias que mobilizaram ações e reações a esse caso, tanto em Santa Luzia como em Belo Horizonte. Durante a pesquisa para a dissertação de mestrado, que versou 
sobre conflitos, violências e formas de legitimação envolvendo as religiões afrobrasileiras, acompanhei alguns eventos que ocorreram em decorrência das imposições restritivas do TAC sobre o Ilê Axé Sangô, sendo o Centro Nacional de Africanidade e Resistência Afro-Brasileira (CENARAB) um importante aglutinador de redes ${ }^{10}$.

O CENARAB foi fundado em 1991 no primeiro Encontro Nacional das Entidades Negras (ENEN), que ocorreu na cidade de São Paulo e nesses recentes 26 anos de história, essa instituição tem atuado em defesa dos direitos das religiões afro-brasileiras e contra a intolerância religiosa, tanto em nível local como também nacional. Atualmente, o CENARAB tem como coordenadora nacional Makota Celinha e sua sede fica no bairro Calafate, em Belo Horizonte. Com o apoio do CENARAB, foram realizados diversos eventos no ano de $2017^{11}$ para expor o caso do llê Axé Sangô e pela luta conta a intolerância religiosa, sendo um deles a Audiência Pública na Assembleia Legislativa de Minas Gerais (ALMG).

Ocorrida no dia 26 de setembro de 2017, a Audiência Pública compôs a 16으 reunião ordinária da Comissão de Participação Popular com a "finalidade de debater o direito à liberdade de culto e o respeito às tradições das religiões afro-brasileiras" ${ }^{12}$. A Audiência Pública foi aberta pela deputada Marília Campos (PT-MG), cuja fala inaugural buscou agregar todas as manifestações afro-religiosas. Segundo a deputada, o objetivo da referida Audiência Pública, além de debater o caso do llê Axé Sangô, consistia também em "externar uma preocupação" da possível propagação de um clima de intolerância religiosa pelo estado de Minas Gerais e pelo país. Nas palavras da deputada:

\footnotetext{
${ }^{10}$ Para a dissertação de mestrado, entrevistei lideranças afro-religiosas de Belo Horizonte em 2017, sendo uma delas Makota Celinha, coordenadora nacional do CENARAB, além de participar de eventos públicos ocorridos em Belo Horizonte e Santa Luzia.

${ }^{11}$ Os eventos mobilizados foram: Reunião no MPMG com o Procurador-Geral Sérgio Tonet a fim de reverter o TAC em agosto de 2017; “Ato público em defesa das tradições de matriz afric ana" em Santa Luzia, agosto de 2017; Recurso no Conselho Nacional do Ministério Público contra o TAC em Brasília, outubro de 2017 e a Audiência Pública na ALMG, setembro de 2017.

${ }^{12}$ Participaram da mesa a deputada Marília Campos do PT (a qual requereu da Audiência Pública), os deputa dos Jean Freire e Geraldo Pimenta, a mbos do PT, pai Luiz do Ilê Axé Sangô, Makota Célia Gonçalves, coordenadora nacional do CENARAB, pai Ricardo de Moura presidente da associação de resistência cultura afro-brasileira Casa de Caridade Pai Jacob do Oriente, Mametu Muiandê, representante do Terreiro Manzo Ngunzo Kaiango, além da verea dora Suzane Duarte de Santa Luzia, Nívea Mônica da Silva, promotora de justiça representante do MPMG, João Carlos de Souza, representante da subsecretaria de política da promoção da igualdade racial e Willian dos Santos, representante da comissão de direitos humanos da OAB/MG (Disponível em https://www.youtube.com/watch?v=mFeOSuPUocg\&t=2315s)
} 
"eu particularmente tenho esse receio, que essa cultura de desrespeito às religiões de matriz africana comece a disseminar em todo o nosso estado, em nosso país. O que seria comprometer a democracia e a liberdade religiosa (...) Pra mim, faltou diálogo em Santa Luzia [no caso do llê Axé Sangô] e essa solução que foi costurada, ela pode disseminar um clima de intolerância por todo o nosso estado" (Deputada Marília Campos, Audiência Pública, 26 de setembro de 2017. Transcrição feita pela autora. Disponível em https://www.youtube.com/watch?v=mFeOSuPUocg\&t=2315s).

O ponto comum em todos os discursos, tanto dos deputados, dos juristas, quanto das lideranças religiosas, foi unificar as variadas manifestações religiosas afro-brasileiras em termos como religiões/tradições/comunidades de matriz africana, além da ideia de que há uma "cultura de desrespeito" a esse grupo que, tal qual uma epidemia, caso não contida, se espalharia pelo estado de Minas Gerais e pelo país, conforme elucidado pela fala da deputada.

A criação de uma macro categoria identitária que apaga as diferenças internas no campo religioso afro-brasileiro é essencial a esse grupo, sobretudo em Belo Horizonte e região metropolitana, onde há uma variedade de manifestações religiosas afrobrasileiras. O contexto religioso da capital mineira e arredores é extremamente poroso, heterogêneo e diversificado - indo desde o Congado e suas práticas religiosas, a Umbanda e suas variações como o Omolocô, além do Candomblé com as diferenças entre as nações ketu, jeje e angola, podendo coexistir mais de uma prática religiosa em um terreiro (MORAIS, 2014). Na contramão do que ocorreu em Salvador e na Bahia, na capital mineira a Umbanda precedeu o Candomblé e foi sob a influência desta que o Candomblé angariou espaço em Belo Horizonte (MORAIS, 2006, 2010). Os primeiros terreiros de Umbanda datam da primeira metade do século $\mathrm{XX}$, enquanto os terreiros de Candomblé vieram a se formar mais tarde, a partir da década de 1960 e tal como aconteceu na capital paulista, contou com a colaboração de grupos de outros estados, sobretudo da Bahia e do Rio de Janeiro (PRANDI, 1991; MORAIS, 2010).

A junção dessas práticas religiosas em uma categoria identitária englobante ficou explícita na fala de pai Luiz, o qual, durante todo o seu discurso, não citou qual a sua religião ou qual prática religiosa é seguida no seu terreiro llê Axé Sangô. Ele não se proclamou como seguido de nenhuma nação de Candomblé ou da Umbanda e tal como falado por ele, "eu tenho tradição e é isso que eu sigo". Portanto, a identidade religiosa 
de Pai Luiz é definida por ele enquanto alguém que tem tradição herdada através da ancestralidade com seus antepassados africanos.

Essa identidade afro-religiosa - povo de terreiro, povo de axé, comunidades tradicionais de matriz africana ou qualquer conjugação entre essas palavras - além de possibilitar o agrupamento de variadas práticas religiosas através de marcadores diferenciais como ancestralidade, tradição e herança cultural de um povo africano no Brasil, possibilita também englobar variadas "raças". Esse é o caso de pai Luiz, cuja identidade racial vi ser questionada durante meu trabalho de campo. Em 2017, uma interlocutora de pesquisa, militante do movimento negro e praticante de Candomblé, ao opinar sobre o caso do Ilê Axé Sangô durante a entrevista falou: "Pai Luiz não é negro, né?! Tem esse lado do embraquecimento do Candomblé (...) mas ele tem um bom caminho, ele tem lutado pela religião"13. Assim, ainda que pai Luiz seja visto como branco por alguns de seus pares, sua identidade afro-religiosa não é questionada, uma vez que ele é um líder religioso e "luta" pela religião. Essa identidade afro-religiosa, portanto, é fundamentada menos em elementos étnico-raciais fenotípicos e mais em elementos como tradição, resistência, luta e ancestralidade. É nesse sentido que chamo essas identidades de englobantes: percebe-se na re-afirmação da identidade o esforço em emergir uma categoria inclusiva a todas as práticas afro-religiosas e também a pessoas de variados perfis étnico-raciais.

Nesse sentido, deve-se chamar atenção a uma diferença entre duas ideias presentes nos discursos identitários na Audiência Pública: uma que aciona um contexto africano no Brasil através da religião, não necessariamente racializado, devido à miscigenação; e outra ideia que aponta as religiões afro-brasileiras como religiões dos negros, como mencionado anteriormente. Cruz (2008) em sua tese sobre relações raciais no Candomblé do Rio de Janeiro, fez uma interessante distinção entre "África" e "negro" e aponta que, apesar de parecerem ideias sinônimas, esses conceitos, quando acionados no Candomblé, podem se referir a contextos diferentes, sendo "África" uma categoria abrangente que remete a uma história, cultura e área geográfica específica, e não necessariamente um contexto racializado ${ }^{14}(2008$, p. 2). Assim, a legitimação da fala

\footnotetext{
13 Entrevista concedida no dia 22 de setembro de 2017.

14 "'África"” poderá apontar para uma realidade universalista de âmbito mais cultural, enquanto que 'negro' trata de um contexto particularista e explicitamente racial' (CRUZ, 2008, p.2).
} 
de pai Luiz, e que permite a ele não só pertencer a esse grupo religioso, mas também se dizer como representante dessas religiões, resulta do acionamento da sua relação ancestral com a África ${ }^{15}$ e não da alusão à sua raça. Como colocado por Cruz, pai Luiz fez o "compartilhamento da alteridade étnico-racial por via ancestral" (2008, p. 143).

Da mesma forma, Sansone, ao pesquisarnegritude no Brasil, aponta para o caráter complexo da identidade negra, a qual, muito além de critérios fenotípicos biológicos, estão associados aos usos de traços culturais tidos como afro-brasileiros e também ao "passado" e à "tradição":

"As categorias dos negros e da negritude são constructos culturais que refletem e distorcem a posição dos negros na sociedade e no sistema local de relações raciais. No Brasil, a negritude não é uma categoria racial fixada numa diferença biológica, mas uma identidade racial e étnica que pode basear-se numa multiplicidade de fatores: o modo de administrar a aparência física negra, o uso de traços culturais associados à tradição afrobrasileira (particularmente na religião, na música e na culinária), o status, ou uma combinação desses fatores. Na América Latina, a negritude é definida em associação com dois conjuntos fundamentais de elementos. $O$ primeiro é uma associação com o 'passado' e a 'tradição'. O segundo é mais amplo e inclui a referência a uma proximidade da natureza, a poderes mágicos, à linguagem corporal, à sexualidade e ao sensualismo" (SANSONE, 2004 , p. 25, 26).

Assim, na Audiência Pública, a ênfase da identidade afro-religiosa está baseada em um passado comum, em uma ancestralidade e tradição cuja origem é a "África" lugar mítico presente no imaginário coletivo desses grupos - e menos em traços raciais, apesar da negritude também está presente e ser um dos elementos dessa identidade afro-religiosa. O próprio nome da categoria mais usada tanto para classificar como para auto-classificar esse grupo religioso, comunidades tradicionais de matriz africana, envolve uma comunidade de prática com algum tipo de relação com a África e não necessariamente a uma comunidade racializada. Tal como falado por Pai Ricardo na Audiência Pública, ancestralidade negra e miscigenação não são opostos:

"A gente pede oportunidade pra vocês entenderem que a gente é circular, não rígidos e duros. Já se passou da hora de toda conversa, toda construção, passar onde tudo sempre se passou nesse país, que foi nos terreiros, na ancestralidade negra, na verdadeira história deste país quando a gente

\footnotetext{
15 “Há uns bons anos atrás, meus avós, meus antepassados lutaram para eu estar aqui hoje” (Fala de Pai Luiz de Odé, Audiência Pública).
} 
fala de caminho, que é a integração de todas as raças. Então eu peço a Xangô que olhe isso, peço a Xangô pois o considero como diretor, condutor das nossas leis e organização enquanto coletivo e bem-estar um com o outro. E em Xangô eu peço proteção" (Pai Ricardo, Audiência Pública, 26 de setembro de 2017. Transcrição feita pela autora. Disponível em https://www.youtube.com/watch?v=mFeOSuPUocg\&t=2315s).

No entanto, deve-se ressaltar que apesar da tentativa em distinguir a criação de identidade afro-religiosa englobante não necessariamente racializada, sobretudo acionando a palavra "África" e não "negro", está implícito a associação entre essas duas categorias. No discurso de pai Luiz, a tradição seguida por ele veio da África e está ligada ao sofrimento dos negros escravizados ${ }^{16}$. Da mesma forma, os próprios convidados à mesa na Audiência Pública revelam a estreita ligação das religiões afro-brasileiras a um grupo específico, "o povo negro": representante da subsecretaria de política da promoção da igualdade racial, representante do CENARAB - instituição que nasceu no seio do movimento negro - além da vereadora de Santa Luzia, Suzane Duarte, cuja fala inicial foi em agradecimento pela ALMG ter acolhido uma "demanda tão importante para o nosso povo negro". Portanto, percebe-se que mesmo envolvendo outros elementos como ancestralidade e tradição, é essencial à identidade afro-religiosa a negritude.

Mesmo Cruz (2008), que tenta diferenciar em sua tese "África" e "negro", reconhece o embricamento íntimo dessas categorias:

"a sinonímia eventual entre "africano" e "negro" encontra-se tão profundamente arraigada no nosso senso comum, ou seja, a cosmologia de nossa sociedade - e de forma tão abrangente - que parece ser impossível estabelecer seus limites. É possível que eu mesmo possa uma vez ou outra possa expressar esta confusão ao longo desta tese" $(2008$, p. 03).

Portanto, por mais que essa categoria comunidades tradicionais de matriz africana seja englobante e até certo ponto "desracializada", ela está intimamente associadaa uma negritude e ao universo simbólico do negro. Nesse sentido, ser praticante de religião afro-brasileira é resistência e perpetuação de uma tradição e ancestralidade negro-africana, mesmo tendo traços fenotipicamente brancos ou mestiços. Assim,

\footnotetext{
16"Será que a luta deles, o choro, a lágrima, o sofrimento que el es tiveram lá, pra hoje a gente tá aqui, foi em vão?" (Fala Pai Luiz de Odé, Audiência Pública).
} 
percebe-se que, neste contexto, estamos diante de um processo de racialização e construção de uma negritude cujas bases se fixam em pressupostos religiosos e elementos como tradição e ancestralidade.

\section{Intolerância religiosa: um outro denominador comum}

Além desses dois elementos da identidade afro-religiosa - acionamento da tradição e da ancestralidade africana - há outro que também gera a “coesão" deste grupo religioso: a experiência da intolerância religiosa. Apesar da pauta da Audiência Pública ter sido sobre liberdade religiosa, somente as religiões afro-brasileiras foram contempladas. A própria finalidade da audiência - "Debater o direito à liberdade de culto e o respeito às tradições das religiões de matriz africana ${ }^{17 "}$ - considera essas religiões alvos de intolerância religiosa. Portanto, intolerância religiosa é vista quase como intrínseca a essas religiões. Acredito que essa ideia foi bem ilustrada na fala inicial da deputada Marília Campos, quando ela expressa seu receio de que "essa cultura de desrespeito às religiões de matriz africana comece a disseminar em todo o nosso estado, e em nosso país".

No processo relacional de criação de fronteiras identitárias que se movem para uma identidade afro-religiosa, a oposição entre um "nós" e "eles" está contrastada com a figura genérica dos evangélicos. Através do jogo de espelhos com os evangélicos sobretudo os pentecostais e neopentecostais - estes são vistos como "os outros", "os intolerantes", enquanto os religiosos afro-brasileiros são tidos como minoria estigmatizada, praticantes e perpetuadores de uma religião milenar e cultural de ancestralidade e tradição onde tem centralidade a África. Portanto, ser vítima de intolerância religiosa - mesmo que potencialmente - seria o marcador de diferença, significante comum gerador de coesão social entre os afro-religiosos. Dessa forma, a organização do grupo religioso afro-brasileiro na esfera pública brasileira tem se dado acionando o discurso da intolerância religiosa, tendo como o par de oposição os "evangélicos intolerantes".

\footnotetext{
${ }^{17}$ (Disponivel em https://www.almg.gov.br/atividade parla mentar/comissoes/internaPauta.html?idCom=585\&dia=26\&m es $=09 \& a n o=2017 \& h r=14: 30 \&$ tpCom=1\&aba=is tabResultado. Acesso 16 de maio de 2018).
} 
Esse argumento vai ao encontro das análises de Morais (2017). Essa autora analisou a categoria "povos e comunidades tradicionais de matriz africana" nas políticas públicas de salvaguarda e promoção da diversidade cultural no Brasil, e aponta esta categoria como emergente na luta contra a intolerância religiosa devido ao embate crescente no espaço público com os evangélicos. Um exemplo mostrado pela autora é a supressão do termo religião nas políticas públicas que citam as religiões afrobrasileiras, como no Plano Nacional de Promoção da Igualdade Racial (BRASIL, 2009) com o uso da categoria "comunidades tradicionais de terreiro" -, e no Plano Nacional de Desenvolvimento Sustentável dos Povos e Comunidades Tradicionais de Matriz Africana (2013) - quando finalmente aflora a expressão povos e comunidades tradicionais de matriz africana. Para a autora, mencionar as religiões afro-brasileiras nos documentos referentes à Política Nacional de Promoção da Igualda de Racial não mais como religiões, e sim como povos ou comunidades - ideias mais ligadas a práticas culturais - é

\footnotetext{
"uma estratégia para se precaver dos embates políticos com parlamentares evangélicos e também com o próprio movimento negro. (...) Conforme a justificativa de representantes do movimento afro-religioso, uma vez que se trata de um estado laico, não se pode ter políticas públicas voltadas para uma denominação religiosa" (MORAIS, 2017, p.279-280).
}

Nesse sentido, intolerância religiosa é um elemento comum gerador de coesão social entre os afro-religiosos e em vários momentos e em diversas falas na Audiência Pública foram comparados os direitos dos "evangélicos" com os direitos dos religiosos afro-brasileiros. A comparação com o "outro" - evangélico - e sua associação como “intolerante" está presente de maneira difusa em várias falas, como colocado por pai Luiz, pai Ricardo e por Makota Celinha:

"eu levei esse questionamento ao promotor: será que na igreja evangélica existe esse isolamento acústico? (...) Ele não soube me responder..." (Pai Luiz)

"Nós temos que trazer para espaços como este essa discussão, e dizer que nós não queremos que ninguém preocupe se eu vou pro céu ou pro inferno, isso é um problema pessoal meu. As pessoas têm que se preocupar que eu tenho que ter o mesmo direito que qualquer outra pessoa tem (...) Se eu acendo a vela, e a vela me atende, eo outro reza com a bíblia, é um problema de cada um na hora de rezar..." (Makota Celinha) 
"Muito complicado viver nesse estado constante medo. E todos têm noção, sabem disso, não é mais velado e ninguém faz nada. Só que nós somos um povo de resiliência, de resistência. Quando comparamos comoutras religiões, é para mostrarque não se tem uma isonomia de tratamento quando se trata das coisas do povo de matriz africana, do povo de terreiro. (...) não queremos mexer no sagrado de ninguém, mas deixa nós com o nosso" (Pai Ricardo)

Com a entrada das igrejas neopentecostais em fins da década de 1970 no campo religioso brasileiro - sobretudo seu maior expoente, a Igreja Universal do Reino de Deus - e com sua difusão nas décadas seguintes, o discurso identitário dos religiosos afrobrasileiros foi se configurando tendo como alteridade os evangélicos, e também os neopentecostais se desenvolveram tendo como alteridade as religiões afro-brasileiras. Nesse sentido, o uso da categoria intolerância religiosa nas Ciências Sociais tem sido uma constante para caracterizar a relação entre neopentecostais e religiões afrobrasileiras.

A emergência dessa categoria "intolerância religiosa" nas Ciências Sociais teve início na década de 2000, como um substituto ao que normalmente vinha sendo chamado de "batalha espiritual", "guerra santa" e "guerra espiritual" neste campo acadêmico para designar uma das características mais destacadas do neopentecostalismo: o acirramento da demonização às religiões afro-brasileiras e a exacerbação da guerra contra o diabo. Mariza Soares (1990), Luiz Eduardo Soares (1993) e André Corten (1996), foram alguns dos primeiros pesquisadores a se atentarem à relação entre esses dois grupos religiosos na década de 1990 e analisaram o conflito dos neopentecostais e das religiões afro-brasileiras como "guerra espiritual", destacando a belicosidade dos neopentecostais para com seus oponentes.

No entanto, um episódio nacionalmente conhecido como o "chute na santa" mudou os rumos das análises sobre a batalha espiritual e os neopentecostais no Brasil. No dia 12 de outubro de 1995, dia de Nossa Senhora Aparecida, o bispo da Igreja Universal do Reino de Deus, Sérgio Von Helde, chutou a imagem da santa em um programa televisivo da Rede Record, no intuito de criticar a veneração católica às imagens. Emerson Giumbelli (2002) se refere a esse episódio como um turning point nos estudos sobre a guerra santa no Brasil. Segundo Almeida (2007) e Pierucci (1996), esse acontecimento levantou discussões e controvérsias, mobilizando grande contingente de atores sociais. Nas palavras de Almeida: “Após o episódio do 'chute na santa' não houve 
nenhum momento de grande controvérsia que tenha mobilizado a grande mídia em torno dos evangélicos no Brasil como naquele momento" (2007: 173). A partir de então, o termo "intolerância religiosa" entra em cena no debate acadêmico para se referir às atitudes beligerantes das igrejas neopentecostais, sobretudo em relação às religiões afro-brasileiras. Vale ressaltar que foi preciso um incômodo à hegemônica Igreja Católica para que o termo intolerância religiosa fosse acionado no debate acadêmico para caracterizar as atitudes beligerantes dos neopentecostais. Almeida (2007) aponta que, mesmo com a repercussão do caso do "chute na santa", os neopentecostais continuaram a demonizar as religiões afro-brasileiras. Silva (2007) também sinaliza nessa direção. Segundo ele, o episódio do "chute na santa":

"mostrou que quando os ataques da IURD dirigem-se diretamente aos símbolos de uma religião majoritária e hegemônica, como o catolicismo, sua eficácia é reduzida. $O$ que não ocorre com os ataques às religiões afrobrasileiras que, em geral, têm se mostrado eficazes tanto na conversão de adeptos, como no comprometimento da imagem pública desta religiosidade" (2007: 221).

Percebe-se, portanto, que entre religiões afro-brasileiras e neopentecostais há tanto aproximação quanto distanciamento (ORO, 2007; SILVA, 2007). No entanto, apesar da centralidade dos "evangélicos" como contraste identitário na identidade afroreligiosa (e vice-versa), deve-se ressaltar que essa relação é permeada por uma distribuição de poder extremamente desigual.

As igrejas neopentecostais - sobretudo a Igreja Universal do Reino de Deus colocaram em curso um processo difamatório contra religiões afro-brasileiras com amplo recurso político ${ }^{18}$ e midiático ${ }^{19}$. Portanto, é dessa extrema assimetria de poder entre as igrejas neopentecostais e as religiões afro-brasileiras que surge o discurso da intolerância religiosa, o qual se formou com base em variados setores da sociedade incluindo a academia. É debaixo do discurso da intolerância religiosa - ou do combate à intolerância religiosa - que o campo religioso afro-brasileiro se movimenta

\footnotetext{
${ }^{18} \mathrm{~A}$ a tuação política de parlamenta res evangélicos tem sido um exemplo do recurso político dessas igrejas e está sendo amplamente discutido, sobretudo, devido à chamada "bancada evangélica" no Congresso Nacional. Para maiores detalhes, ver ORO (2005) e MARIANO (2016).

19 Vide o famoso livro do bispo Edir Macedo Orixás, caboclos e guias: deuses ou demônios?, o qual, mesmo sendo alvo de processos judiciais e com nítidas representações negativas do universo religioso afrobrasileiro, vendeu mais de 3 milhões de cópias, tendo 17 edições lançadas, sendo que a primeira edição foi feita em 1997.
} 
internamente, reúne lideranças, articula redes e se comunica com a sociedade. Diferentemente dos modelos associativos-burocráticos em federações presentes na década de 1970 como forma de união das religiões afro-brasileiras, o "novo" elemento de coesão desse grupo religioso na atualidade parte do discurso conta a intolerância religiosa e envolve, conforme visto, políticos, juristas, lideranças religiosas, ONGs e movimento negro (ORTIZ, 1978).

Portanto, tradição, ancestralidade com a África e intolerância religiosa são os elementos acionados para definir o grupo de religiosos afro-brasileiros como culturalmente distintos e dotados de bases políticas. Suas políticas de identidade têm em comum uma história compartilhada de desenraizamento e sofrimento forçado, constantemente estigmatizada e atualmente ameaçada pelo belicoso ethos neopentecostal. Dessa forma, o que diferencia o grupo religioso afro-brasileiro não é mais a relação entre brancos e negros, mas a relação entre evangélicos e religiosos afrobrasileiros, a qual, entretanto, não deixa de envolver um processo de racialização, quando os religiosos afro-brasileiros acionam sua ancestralidade com a África.

\section{Bibliografia}

ALMEIDA, Ronaldo. Dez anos do "chute na santa": a intolerância com a diferença. In. SILVA, Vagner (org.). Intolerância religiosa: impactos do neopentecostalismo no campo religioso afro-brasileiro. São Paulo: EDUSP, 2007.

BARTH, Fredrik. "Grupos étnicos e suas fronteiras". In P. Poutignat e Jocelyne Streiffe-Fenart.Teorias da Etnicidade. São Paulo: UNESP. P. 185-227, 1998.

$$
\text { “Temáticas permanentes e emergentes na análise da }
$$

etnicidade", in Hans Vermeuelen e Cora Govers. Antropologia da etnicidade. Para além de "Ethnic Groups and Boundaries", Lisboa: Fim de Século, 19-44, 2003.

BASTIDE, Roger. O Candomblé da Bahia: rito nagô. São Paulo: Companhia das Letras, 2001.

As religiões africanas no Brasil. Vol.1. USP, 1971.

CASTANHA, Taísa Domiciano. Religiões afro-brasileiras em Belo Horizonte e região metropolitana: violências, conflitos e legitimação. Dissertação de mestrado. PPGSUFMG, 2018. 
CRUZ, Robson Rogério. 'Branco não tem santo': representações de raça, cor e etnicidade no candomblé. Tese de doutorado. PPGSA-UFRJ, 2008.

COSTA, Sérgio. Política, esfera pública e novas etnicidades. Revista Internacional Interdisciplinar - INTERTHESIS - PPGICH UFSC, 2013.

ERIKSEN, Thomas Hylland. Ethnicity \& Nationalism: Anthropological Perspectives. London: Pluto Press, 2010.

FURTADO, Cláudio. Verbete Raça. Dicionário Crítico das Ciências Sociais dos Países de Fala Portuguesa. Salvador: Edufb, 2014.

GIUMBELLI, Emerson. O fim da religião: dilemas da liberdade religiosa no Brasil e na França. São Paulo: Attar Editorial, 2002.

MARIANO, Ricardo. Expansão e ativismo político de grupos evangélicos conservadores: secularização e pluralismo em debate. Civitas, Porto Alegre, v. 16, n. 4, p. 710-728, 2016.

MORAIS, Mariana Ramos. O Candomblé na Metrópole: a construção da identidade em dois terreiros de Belo Horizonte. Dissertação de mestrado, PUC-MG, Belo Horizonte, 2006.

. Nas teias do sagrado - Registros da religiosidade afrobrasileira em Belo Horizonte. Espaço Ampliar, Belo Horizonte, 2010.

MORAIS, Mariana Ramos e JAYME, Juliana Gonzaga. Povos e comunidades tradicionais de matriz africana: uma análise sobre o processo de construção de uma categoria discursiva. Civitas, Porto Alegre, v. 17, n. 2, p. 268-283, maio-ago. 2017.

NASCIMENTO, Maria Cristina. Movimento Social Negro (MSN) e religiões afrobrasileiras: questões identitárias e a promoção da igualdade racial. Cadernos do Ceas, Salvador/Recife, n. 240, p. 185-216, jan./abr., 2017.

ORO, Ari Pedro. Intolerância Religiosa lurdiana e Reações Afro no Rio Grande do Sul. In: Intolerância religiosa: impactos do neopentecostalismo no campo religioso afrobrasileiro. (Org.: Silva, Vagner Gonçalves). São Paulo: EDUSP, 2007.

ORTIZ, Renato. A morte branca do feiticeiro negro: Umbanda; integração de uma religião numa sociedade de classes. Petropolis: Vozes, 1978.

PEDDE, Valdir; SANTOS, Everton; NUNES, Margarete Fagundes. Política, religião e etnicidade: relações e deslocamento de fronteiras. Revista Sociedade e Estado - Volume 26 Número 2 Maio/Agosto, 2011. 
PRANDI, Reginaldo. Os candomblés de São Paulo: a velha magia na metrópole nova. São Paulo: HUCITEC: Editora da Universidade de São Paulo, 1991. De africano a afro-brasileiro: etnia, identidade e religião. REVISTA USP, São Paulo, n.46, p. 52-65, junho/agosto 2000.

RODRIGUES JÚNIOR, Nilton. Liberdade religiosa ou uma questão de política de identidade? Tese de doutorado, PPGSA-UFRJ, 2012.

RODRIGUES, Nina. Os Africanos no Brasil. São Paulo: Editora Nacional; Brasília: UnB, 2010.

SANSONE, Lívio. Negritude sem etnicidade. Salvador: Edufba 2004 - Verbete Etnicidade. Dicionário Crítico das Ciências Sociais dos Países de Fala Portuguesa. Salvador: Edufb, 2014.

SILVA, Vagner Gonçalves. Candomblé e Umbanda: caminhos da devoção brasileira. São Paulo: Ática, 1994.

. Neopentecostalismo e religiões afro-brasileiras: significados do ataque aos símbolos da herança religiosa africana no Brasil contemporâneo. MANA 13(1): 207-236, 2007b.

SOARES, Mariza de Carvalho. Guerra santa no país do sincretismo. In: LANDIM, Leilah (org.). Sinais dos tempos: diversidade religiosa no Brasil. Cadernos do ISER, Rio de Janeiro, ISER, 23, 1990.

VERMEUELEN, Hans e GOVERS, Cora. Antropologia da etnicidade. Para além de "Ethnic Groups and Boundaries", Lisboa: Fim de Século, 2003. 